VOL.I NO. 2 EDISI JULI-DESEMBER 2018. ISSN. 262 1-2684

\title{
TINJAUAN FILOSOFIS TERHADAP PENGEMBANGAN KURIKULUM PENDIDIKAN AGAMA KRISTEN
}

\author{
Dr. Dyulius Thomas Bilo, M.Th. \\ Sekolah Tinggi Teologi Injili Arastamar (SETIA) Jakarta, \\ greatshine@sttsetia.ac.id
}

\begin{abstract}
ABSTRAK
Tulisan ini dipandu rumusan masalah yaitu: (1) bagaimana memahami pengertian filsafat bagi pengembangan kurikulum pendidikan Kristen, (2) bagaimana memahami pengertian kurikulum pendidikan Kristen untuk kajian filosofis, (3) bagaimana memahami manfaat filsafat bagi pengembangan kurikulum pendidikan Kristen, (4) bagaimana memahami pentingnya filsafat bagi pengembangan kurikulum pendidikan Kristen, (5) apakah tinjauan filosofis kedudukan Alkitab dalam pengembangan Kurikulum Pendidikan Kristen, (6) apakah tinjauan filosofis Alkitab Penentu isi pengembangan Kurikulum Pendidikan Kristen, (7) apakah tinjauan filosofis Alkitab penentu arah dan tujuan pengembangan Kurikulum Pendidikan Kristen. Tujuan penelitian ini adalah: (1) menjelaskan bagaimana memahami pengertian filsafat bagi pengembangan kurikulum pendidikan Kristen, (2) bagaimana memahami pengertian kurikulum pendidikan Kristen untuk kajian filosofis, (3) menjelaskan bagaimana memahami manfaat filsafat bagi pengembangan kurikulum pendidikan Kristen, (4) menjelaskan bagaimana memahami pentingnya filsafat bagi pengembangan kurikulum pendidikan Kristen, (5) menjelaskan apakah tinjauan filosofis kedudukan Alkitab dalam pengembangan Kurikulum Pendidikan Kristen, (6) menjelaskan apakah tinjauan filosofis Alkitab Penentu isi pengembangan Kurikulum Pendidikan Kristen, (7) menjelaskan apakah tinjauan filosofis Alkitab penentu arah dan tujuan pengembangan Kurikulum Pendidikan Kristen. Penelitian ini menggunakan pendekatan deskripsi literatur kepustakaan. Hipotesis penelitian ini adalah patut diduga pentingnya fondasi filosofis dalam pengembangan kurikulum pendidikan Kristen. Hasil penelitian berdasarkan rumusan masalah pertama hasilnya adalah telah dijelaskan pengertian filsafat bagi pengembangan kurikulum pendidikan Kristen. Rumusan masalah kedua hasilnya bahwa telah dijelaskan pengertian kurikulum pendidikan Kristen untuk kajian filosofis. Rumusan masalah ketiga hasilnya adalah telah dijelaskan manfaat filsafat bagi pengembangan kurikulum pendidikan Kristen. Rumusan masalah keempat hasilnya adala telah dijelaskan pentingnya filsafat bagi pengembangan kurikulum pendidikan Kristen. Rumusan masalah kelima hasilnya adalah telah dijelaskan tinjauan filosofis kedudukan Alkitab dalam pengembangan Kurikulum Pendidikan Kristen. Rumusan masalah keenam hasilnya adalah telah dijelaskan tinjauan filosofis Alkitab Penentu isi pengembangan Kurikulum Pendidikan Kristen dan rumusan masalah ketujuh hasilnya adalah telah dijelaskan tinjauan filosofis Alkitab penentu arah dan tujuan pengembangan Kurikulum Pendidikan Kristen. Berdasarkan hipotesis yang diajukan ternyata ditemukan ada kepentingan fondasi filosofis dalam pengembangan kurikulum
\end{abstract}


pendidikan Kristen. Dari hasil penelitian ini disarankan dan direkomendasi bahwa setiap pelaku pendidikan Kristen perlu memahami fondasi filosofis dalam pengembangan kurikulum pendidikan Kristen, karena hal itu berpengaruh secara signifikan bagi pemikiran dan praktik pendidikan. Oleh sebab itu para pelaku pendidikan Kristen perlu mendalami pemikiran-pemikiran filosofis kristiani secara alkitabiah guna mengembangkan dan menerapkan kurikulum pendidikan Kristen dalam kehidupan dan pengajarannya.

\section{Kata Kunci: Filosofis, Pengembangan, Kurikulum, Pendidikan, Agama, Kristen}

\section{Pendahuluan}

Salah satu fondasi (asas, dasar, landasan) penting dalam pengembangan kurikulum termasuk kurikulum pendidikan Kristen adalah fondasi filosofis. Sebagaimana diketahui dari teori-teori pendidikan bahwa secara umum fondasifondasi dari pengembangan kurikulum adalah fondasi filosofis, psikologis, sosiologi, dan teknologis. Menurut Wina Sanjaya ada tiga landasan pengembangan kurikulum, yakni landasan filosofis, psikologis, dan landasan sosiologis-teknologis. ${ }^{1}$ Sedangkan Oemar Hamalik memaparkan landasan-landasan kurikukulum yaitu landasan filsafat dan pendidikan nasional, landasan sosial budaya dan agama, landasan perkembangan peserta didik, landasan keadaan lingkungan, landasan kebutuhan pembangunan, dan landasan perkembangan ilmu pengetahuan dan teknologi. ${ }^{2}$ Sedangkan pendapat S. Nasution bahwa asas-asas kurikulum adalah asas filosofis, asas psikologis, asas sosiologis, dan asas organisatoris. ${ }^{3}$

Salah satu pendidik kristiani Robert W. Pazmino menyebutkan fondasi-fondasi pendidikan Kristen adalah fondasi alkitabiah, teologis, filosofis, historis, sosiologis, psikologis, dan fondasi kurikulum. ${ }^{4}$ Charlotte Mason (1842-1923) seorang pendidik dan pembaharu pendidikan Kristen di Inggris diawal abad 20 pernah menuliskan, "sebagaimana aliran air tidak bisa naik lebih tinggi daripada sumbernya, maka tidak akan ada upaya penyidikan apa pun yang bisa melampaui seluruh skema dari pemikiran asal mulanya." ${ }_{5}$ Pazmino mencermati serius hal ini dengan mengatakan bahwa filosofi pendidikan berusaha mengartikulasikan sebuah skema pemikiran yang sistematis dan memberikan kehidupan yang berfungsi untuk memandu praktik pendidikan. Hal ini krusial karena seperti yang diimplikasikan oleh Mason, pendidikan adalah buah dari akar filosofisnya. Maka tantang bagi pendidik pendidik Kristen adalah menyusun suatu filosofi pendidikan yang bersifat eksplisit dan konsisten dengan cara pandang kristiani sementara tetap memberi tempat bagi terjadinua paradoks. ${ }^{6}$

Berangkat dari pemikiran ini, maka penulis memandang penting mendalami fondasi filosofi pendidikan apalagi berkaitan dengan pengembangan Kurikulum

\footnotetext{
${ }^{1}$ Wina Sanjaya, Kurikulum dan Pembelajaran (Jakarta: Kencana Prenada Media Group, 2009), 42.

${ }^{2}$ Oemar Hamalik, Kurikulum dan Pembelajaran (Jakarta: Bumi Aksara, 2011), 19.

${ }^{3}$ S. Nasution, Asas-asas Kurikulum (Jakarta: Bumi Aksara, 2008), 11.

${ }^{4}$ Robert W. Pazmino, Fondasi Pendidikan Kristen (Jakarta: BPK. Gunung Mulia, 2012), 3-5.

${ }^{5}$ Charlotte Mason, Home School Education, Home Education Series vol. 8, edisi ke-6 (Oxford Scrivener, 1953), ix

${ }^{6}$ Robert W. Pazmino, Fondasi Pendidikan Kristen, 110.
} 
Pendidikan Kristen. Dalam tulisan ini difokuskan pada "fondasi filosofis dalam pengembangan kurikulum Pendidikan Kristen" dengan sub bahasan: Memahami pengertian filsafat bagi pengembangan kurikulum pendidikan Kristen, memahami pengertian kurikulum pendidikan Kristen untuk kajian filosofis, memahami manfaat filsafat bagi pengembang kurikulum pendidikan Kristen, memahami pentingnya filsafat bagi pengembangan kurikulum pendidikan Kristen, tinjauan filosofis kedudukan Alkitab dalam pengembangan kurikulum pendidikan Kristen, tinjauan filosofis Alkitab penentu isi pengembangan kurikulum pendidikan Kristen, tinjauan filosofis Alkitab penentu arah dan tujuan pengembangan kurikulum pendidikan Kristen, dan penutup.

\section{PEMBAHASAN}

\section{Memahami Pengertian Filsafat bagi Pengembangan Kurikulum Pendidikan Kristen}

Kata filsafat atau philosophy berasal dari kata Yunani yang terdiri dari akar kata philein yang berarti cinta, dan sophia yang berarti kebijaksanaan. Secara etimologi, filsafat bisa berarti mencintai atau mencari kebijaksanaan. ${ }^{7}$

Menurut Anthony Preus (2007), kata falsafah atau filsafat merupakan serapan dari bahasa Arab, yang juga diambil dari bahasa Yunani "philosophia". Menurut bahasa, kata ini merupakan kata majemuk dan berasal dari kata-kata philia artinya persahabatan atau cinta dan shopia artinya kebijaksanaan. Sehingga arti semantiknya adalah seorang pencinta kebijaksanaan atau ilmu. Istilah lain yang juga sering digunakan dan dianggap mengandung makna yang sama, yaitu kata philare atau philo yang berarti cinta; dalam arti yang luas yaitu ingin dan oleh karena itu berusaha untuk mencapai yang diingingkan. Orang yang cinta kepada ilmu pengetahuan disebut philosopher, yang dalam bahasa Arab sebagai failasuf. Pencinta pengetahuan ialah orang yang menjadikan pengetahuan sebagai tujuan hidupnya, atau perkataan lain mengabdikan dirinya kepada pengetahuan. Dalam bahasa Inggris digunakan istilah philosophy, yang juga berarti filsafat yang lazim diterjemahkan sebagai cinta kearifan. Akar kata ini yaitu kata philos dan sophos. Philos gemar atau cinta, dan sophos artinya bijaksan na atau arif (wise). Menurut pengertiannya yang semula dari zaman Yunani kuno, filsafat berarti cinta kearifan. Cakupan sophia luas sekali tidak hanya berarti kearifan, tetapi meliputi kebenaran, pengetahuan yang luas, kebijaksanaan intelektual, pertimbangan sehat, keluasan pikiran, kelapangan dalam memahami sesuatu, berpikir secara bebas, berpikir secara mendalam, dan berpikir secara sungguh-sungguh. ${ }^{8}$

Philosophia pertama kali dimunculkan oleh Pythagoras. Namun orang Yunani pertama kali diberi gelar filsuf justru Thales (640-546 SM) dari Mileta (sekarang di pesisir barat Turki). Thales mendirikan aliran filsafat alam semesta atau kosmos. Menurutnya, filsafat adalah suatu penelaahan terhadap alam semesta untuk mengetahui asal mulanya, unsurnya, dan kaidahnya. ${ }^{9}$

\footnotetext{
${ }^{7}$ Khoe Yao Tung, Filsafat Pendidikan Kristen (Yogyakarta: Andi, 2013), 3.

${ }^{8}$ Muktar Latif, Orientasi ke Arah Pemahaman Filsafat Ilmu (Jakarta: Prenadamedia Group, 2014),

${ }^{9}$ Latif, Orientasi ke Arah Pemahaman Filsafat Ilmu, 44
} 
Berikut akan dipaparkan singkat beberapa pemikir tentang pengertian filsafat. Menurut Plato (427- 347 SM) mengatakan filsafat adalah pengetahuan tentang segala yang ada, filsafat yaitu ilmu pengetahuan yang dapat memenuhi keinginan mereka yang berminat mencapai kebenaran yang sesungguhnya. Sedangkan Aristoteles (384422 SM), murid Plato, dia mengatakan filsafat melakukan telaah tentang sebab dan asas segala benda. Filsafat adalah ilmu pengetahuan yang meliputi kebenaran yang terkandung didalamnya ilmu metafisika, logika, retorika, etika, ekonomi, politik, dan estetika. Menurut Marcus Tullius Cicero (106-43 SM) mengatakan, bahwa filsafat adalah pengetahuan tentang sesuatu yang maha agung dan usaha untuk mencapainya. Al-Farabi yang wafat pada $950 \mathrm{M}$, seorang filsuf muslim terbesar sebelum Ibn Sina yang mengatakan filsafat, yaitu ilmu pengetahuan tentang alam yang maujud dan bertujuan menyelidiki hakikat yang sebenarnya.

Menurut Descartes (2590-1650), filsafat adalah kumpulan segala ilmu pengetahuan dimana Tuhan, alam, dan manusia menjadi pokok penyelidikan yang utama. Imanuel Kant (1724-1804) filsafat adalah ilmu pengetahuan yang menjadi pokok dan pangkal dari segala pengetahuan yang tercakup di dalamnya metafisika, etika, agama, dan antropologi. Ia memaparkan bahwa filsafat merupakan ilmu pokok dan pangkal segala pengetahuan yang mencakup empat persoalan, yaitu: (1) apakah yang dapat kita ketahui (dijawab dengan metafisika); (2) apakah yang boleh kita kerjakan (dijawab dengan etika); (3) sampai dimanakah pengharapan kita (dijawab oleh agama); dan (4) apakah yang dinamakan manusia itu? (dijawab dengan antropologi). ${ }^{10}$

Harold Titus mengemukakan empat pengertian tentang filsafat, yakni: (1) satu sikap tentang hidup dan tentang alam semesta (philosophy is an attitude toward life and the universe); (2) filsafat yaitu satu metode pemikiran reflektif dan penyelidikan akaliah (philosophy is a method of reflective thinking and reasoned inquired); (3) filsafat yaitu satu perangkat masalah (philosophy is a group of problems); dan (4) filsafat adalah satu perangkat teori atau isi pikiran (philosophy is a group of system of thought). ${ }^{11}$ Dalam pengertian yang lebih luas, Harold Titus, mengemukakan pengertian filsafat sebagai berikut:

a. Filsafat adalah sekumpulan sikap dan kepercayaan terhadap kehidupan dan alam yang biasanya diterima secara kritis.

b. Filsafat adalah suatu proses kritik atau pemikiran terhadap kepercayaan dan sikap yang sangat kita junjung tinggi

c. Filsafat adalah usaha untuk mendapatkan gambaran keseluruhan

d. Filsafat adalah analisa logis dari bahasan serta penjelasan tentang arti kata dan konsep

e. Filsafat adalah sekumpulan problema yang langsung mendapatkan gambaran perhatian dari manusia dan yang dicarikan jawabannya oleh ahli filsafat $^{12}$

Menurut John Chaffee, penulis buku "The Philosopher's Way", mendefinisikan filsafat tidak terlepas dari empat aspek penting, yaitu:

a. Aspek wonder (keheranan). Mempelajari filsafat karena keheranan, pertanyaan akan sesuatu yang ada atau terjadi.

\footnotetext{
${ }^{10}$ Latif, Orientasi ke Arah Pemahaman Filsafat Ilmu, 44

${ }^{11}$ Latif, Orientasi ke Arah Pemahaman Filsafat Ilmu, 45

${ }^{12}$ H. Jalaluddin dan Abullah Idi, Filsafat Pendidikan: Manusia, Filsafat dan Pendidikan, 12.
} 
b. Aspek wisdom (kebijaksanaan). Mempelajari filsafat karena mencari esensi dari sesuatu, mencari kebenaran, dan mencintai kebijaksanaan.

c. Aspek truth (kebenaran). Filsafat adalah ilmu yang mempertimbangkan kebenaran-kebenaran hakiki

d. Aspek a dynamic process (proses dinamik). Mempelajari filsafat berawal dari proses, dari runtut konflik, opini-opini, dan terus menerus sampai memperoleh jawaban yang memuaskan.

Rosenberg mengungkapkan filsafat berkenaan dengan dua pertanyaan, yaitu pertama pertanyaan tentang ilmu, yakni fisika, biologi, dan sosial. Pertanyaan kedua tentang ilmu yang tidak terjawab pada persoalan yang pertama. Harun Nasution, filsafat adalah berpikir menurut tata tertib (logika) dengan bebas (tak terikat tradisi, dogma, atau agama) dan dengan sedalam-dalamnya, sehingga sampai ke dasar persoalan. Fuad Hasan menyatakan, filsafat adalah suatu ikhtiar untuk berpikir radikal dalam arti mulai dari radic suatu gejala dari akar suatu hal yang hendak dipermasalahkan, dan dengan jalan penjajakan yang radikal filsafat berusaha untuk sampai kepada kesimpulan yang universal.13

Menurut $H$. Jalaluddin dan Abdullah Idi, filsafat adalah cinta kepada ilmu pengetahuan atau kebenaran, suka kepada hikmat, dan kebijaksanaan. Jadi orang yang berfilsafat adalah orang yang mencintai kebenaran, berilmu pengetahuan, ahli hikmat dan bijaksana.14 Jika memperhatikan berbagai pendapat di atas, dapat disimpulkan: (1) filsafat adalah suatu telaah kefilsafatan tentang suatu objek tertentu yang mengandalkan pemikiran yang mendalam/radic dengan menggunakan hukum skeptis dan dialektika untuk melahirkan suatu ilmu yang melandaskan objeknya pada Tuhan, alam, dan manusia. (2) bahwa filsafat adalah kecintaan kepada ilmu pengetahuan, kesukaan pada hikmat dan kebijaksanaan, kedekatan dan keakraban kepada kebenaran, dan persahabatan kepada seluruh kebaikan, kebenaran, dan keadilan.

Menjadi esensial dalam mempertimbangkan cara pandang kristiani untuk mengeksplorasi pemikiran filosofis suatu pendidikan dan pengembangannya. Sebab sebuah cara pandang bisa didefinisikan sebagai sekumpulan asumsi mendasar yang melahirkan pola pikir dan tindakan. Maka menurut Arthur F. Holmes cara pandang kristiani terdiri dari sekumpulan kepercayaan Kristen yang fundamental yang paling mumpuni dalam menjelaskan hubungan Allah dengan ciptaan. Ia mengatakan bahwa sebuah cara pandang yang kristiani apabila memiliki ciri-ciri: (1) mempunyai tujuan yang holistik, yang berusaha melihat keseluruh area kehidupan dan pemikiran secara integratif; (2) menggunakan pendekatan yang memberikan suatu perspektif, dengan cara menilai segala sesuatu berdasarkan cara pandang yang sudah dianut seseorang sebelumnya dengan tujuan untuk memperoleh suatu kerangka berpikir yang terintegratif; (3) menyajikan suatu proses yang eksploratif, dengan cara menyelidiki hubungan satu area kehidupan dengan area lainnya dari perspektif yang utuh; (4) bersifat pluralistik sehingga perspektif dasar yang sama bisa diartikulasikan dengan berbagai cara yang berbeda-beda; dan (5) menunjukkan hasil berupa tindakan, yang dihasilkan dari apa yang kita pikirkan, apa yang kita nilai berharga dan apa yang akan kita lakukan. ${ }^{15}$ Oleh karena itu tugas pendidik Kristen pertama-tama adalah

\footnotetext{
${ }^{13}$ Latif, Orientasi ke Arah Pemahaman Filsafat Ilmu, 45.

${ }^{14}$ H. Jalaluddin dan Abullah Idi, Filsafat Pendidikan: Manusia, Filsafat dan Pendidikan, 9.

${ }^{15}$ Arthur F. Holmes, ed., The Making of a Chritian Mind; A Christian Worldview and the Academic Enterprise (Downers Grove, IL:InterVarsity, 1985), 17.
} 
mengeksplorasi cara pandang kristianinya yang akan mempunyai implikasi langsung dan hasil berupa tindakan bagi pendidikan.

\section{Memahami Pengertian Kurikulum Pendidikan Kristen untuk Kajian Filosofis}

Pada zaman Yunani kuno, kurikulum dikaitkan dengan pelari dan pacuan kuda. Dimana istilah kurikulum yang berasal dari kata curir (pelari) dan curere (tempat berpacu). Pada waktu itu kurikulum hanya diartikan sebagai jarak yang harus ditempuh oleh seorang pelari mulai dari start sampai finish untuk memperoleh medali/penghargaan. ${ }^{16}$

Kemudian dari istilah tersebut digunakan dalam dunia pendidikan, misalnya kurikulum adalah sejumlah mata pelajaran yang harus ditempuh oleh seorang siswa dari awal sampai akhir program pelajaran untuk memperoleh penghargaan dalam bentuk ijazah. ${ }^{17}$ Atau sejumlah mata kuliah di perguran tinggi, yang harus ditempuh untuk mencapai suatu ijazah atau tingkat.18

Dalam Kamus "Webster's New International Dictionary" tahun 1953 telah memberikan arti pada istilah kurikulum, yaitu sebagai sejumlah pelajaran yang ditetapkan untuk dipelajari oleh murid di sekolah atau perguruan tinggi, untuk memperoleh ijazah atau gelar dan keseluruhan mata pelajaran yang ditawarkan oleh lembaga pendidikan atau departemen tertentu. Dari konsep ini kurikulum dipandang sebagai mata pelajaran biasanya erat kaitannya dengan usaha untuk memperoleh ijazah. Ijazah sendiri menggambarkan kemampuan. Artinya, apabila siswa telah berhasil mendapatkan ijazah berarti ia telah menguasai pelajaran sesuai dengan kurikulum yang berlaku. Kemampuan tersebut tercermin dalam nilai setiap mata pelajaran yang terkandung dalam ijazah itu. Siswa yang belum memiliki kemampuan atau belum memperoleh nilai berdasarkan standar tertentu tidak akan mendapatkan ijazah, walaupun mungkin saja mereka telah mempelajari kurikulum tersebut.

Pengertian kurikulum juga berorientasi kepada isi atau materi pelajaran (content oriented). Proses pembelajaran di sekolah yang menggunakan konsep kurikulum demikian, penguasaan isi pelajaran merupakan sasaran akhir proses pendidikan. Untuk mengecek apakah siswa telah menguasai materi pelajaran atau belum biasanya dilaksanakan tes hasil belajar. ${ }^{19}$

Kurikulum tidak hanya pada kegiatan di dalam kelas, tetapi mencakup juga kegiatan-kegiatan yang dilakukan siswa di luar kelas. Seperti dikatakan oleh Saylor, Alexander dan Lewis (1974) bahwa kurikulum upaya sekolah untuk mempengaruhi siswa supaya belajar, baik di dalam ruangan kelas, di halaman sekolah, maupun di luar sekolah. ${ }^{20}$ Sanjaya menegaskan bahwa kalau kurikulum dianggap sebagai pengalaman atau seluruh aktivitas siswa, maka untuk memahami kurikulum sekolah, tidak cukup hanya dengan melihat dokumen kurikulum sebagai suatu program tertulis, akan tetapi juga bagaimana proses pembelajaran yang dilakukan pada anakanak didik baik di sekolah maupun di luar sekolah. ${ }^{21}$

\footnotetext{
${ }^{16}$ Asep Herry Hernawan, "Pengertian, Dimensi, Fungsi dan Peranan Kurikulum”, dalam Toto Ruhimat (Koordinator Tim Pengembang MKDP Kurikulum dan Pembelajaran), Kurikulum dan Pembelajaran (Jakarta: Rajawali Pers, 2011), 2

${ }^{17}$ Hernawan, "Pengertian, Dimensi, Fungsi dan Peranan Kurikulum", 2

${ }^{18}$ S.Nasution, Asas-asas Kurikulum (Jakarta: Bumi Aksara, 2008), 2

${ }^{19}$ Sanjaya, Kurikulum dan Pembelajaran (Jakarta: Kencana Prenada Media Group, 2009), 4

${ }^{20}$ Hernawan, "Pengertian, Dimensi, Fungsi dan Peranan Kurikulum", 2

${ }^{21}$ Sanjaya, Kurikulum dan Pembelajaran, 6
} 
Kurikulum sebagai suatu program atau rencana pembelajaran menjadi tekanan dari Undang-Undang Nomor 20 Tahun 2003 tentang Sistem Pendidikan Nasional dikatakan bahwa kurikulum adalah seperangkat rencana dan pengaturan mengenai isi dan bahan pelajaran serta cara yang digunakan sebagai pedoman penyelenggaraan kegiatan belajar mengajar. Yang dimaksud dengan isi dan bahan pelajaran untuk mencapai tujuan penyelanggaraan satuan pendidikan yang bersangkutan dalam rangka upaya pencapaian nasional. Namun seiring waktu dan perkembangan pengetahuan, maka pada akhirnya beragam tafsiran para ahli mengenai pengertian kurikulum. Dari penelusuran penulis sebagian ahli berpendapat bahwa kurikulum sebagai mata dan isi pelajaran, pengalaman belajar siswa, suatu program atau rencana belajar. 22

Bagaimana dengan kurikululum pendidikan Kristen?, Randolph C. Miller dalam bukunya "Education for Christian Living" mengungkapkan pengertian kurikulum pendidikan Kristen berdasarkan "International Council of Religious Educational" bahwa definisi kurikulum PAK adalah pengalaman si pelajar dibawah bimbingan." 23 Menurut Eli Tanya segala pengalaman murid di dalam rumah tangga, gereja, sekolah dan masyarakat digunakan untuk mencapai tujuan pendidikan gereja.

Lois E. LeBar mengatakan kurikulum dalam orientasi alkitabiah dapat didefinisikan sebagai kegiatan-kegiatan yang berkaitan dengan isi berotoritas yang dibimbing atau dilaksanakan oleh kepemimpinan Kristen agar dapat membawa para siswa satu langkah lebih dekat kepada kedewasaan di dalam Kristus. Inti kurikulum pendidikan Kristen adalah berbagai kegiatan terencana yang menghubungkan murid dengan Alkitab dan Alkitab dengan kehidupan untuk mencapai keserupaan dengan Kristus. ${ }^{24}$

Menurut penekanannya, arti kurikulum yang berpusatkan pada isi (contentcentered curriculum) artinya kurikulum memusatkan pelajaran Alkitab, membahas bagian-bagian Alkitab satu persatu. Kurikulum yang berpusatkan pengalaman (experience-centered curriculum) dimana isinya menitikberatkan pada pengalaman murid, lalu menghubungkannya dengan Alkitab dan atau iman Kristen. Untuk mengarahkan para pelaku pendidikan Kristen dalam mempertimbangkan antara konten kurikulum dan pengalaman peserta didik, LeBar menasihatkan "Konten Kristen tampa disertai pengamana adalah kosong dan pengalaman tanpa disertai konten adalah buta." 25

Pazmino menegaskan bahwa tantangan bagi penyusun dan pengembang kurikulum pendidikan Kristen adalah menggabungkan atau mencampurkan baik konten Kristen maupun pengalaman sehingga pikiran dan kehidupan peserta didik akan dipengaruhi dan diubahkan oleh kebenaran Allah. Terlalu berfokus pada konten dalam ortodoksi (kepercayaan yang benar) bisa membuat kita mengabaikan dimensi penting dari pengalaman Kristen, yang tanpanya pendidikan Kristen menjadi kosong. Sejalan dengan itu, kalau kita terlalu berfokus pada pengalaman dalam ortopraksis (praktik yang benar) kita bisa saja mengabaikan dimensi penting dari konten Kristen yang tanpanya pendidikan Kristen menjadi buta. Kurikulum yang efektif menyatukan

\footnotetext{
${ }^{22}$ Dyulius Thomas Bilo, "Fondasi Alkitabiah Dalam Pengembangan Kurikulu, Pendidikan Kristen" dalam Melayani Dengan SETIA: Misi GKSI Dalam Tangan Tuhan (Jakarta: Delima-BPS GKSI, 2018), 138

${ }^{23}$ Eli Tanya, Gereja dan Pendidikan Agama Kristen (Cipanas: STTC, 2006), 28

${ }^{24}$ Lois E. LeBar, Education That Is Christian (Malang: Gandum Mas, 2006), 307, 340

${ }^{25}$ Lois E. LeBar, "Curriculum," dalam An Introduction to Evangelical Christian Education, ed. J. Eward Hakes (Chicago:Mody, 1964), 89
} 
konten dan pengalaman kristiani dan sebagai dampaknya kurikulum tersebut berpotensi mengubahkan kehidupan (transformasi). Potensi ini membutuhkan partisipasi aktif dan reseptif dari orang-orang yang berusaha belajar dan terbuka pada perintah Tuhan yang dimediasi lewat pendidik. ${ }^{26}$

\section{Memahami Manfaat Filsafat bagi Pengembangan Kurikulum Pendidikan Kristen}

Belajar filsafat akan membentu kita, terutama dalam pemahaman dan wawasan yang dibutuhkan, untuk membuat pilihan cerdas dalam memenuhi potensi kita sebagai individu. Paul A. Kienel, cs., mengutip pemikiran Peter P.Person yang memberikan analogi bagaimana kegunaan atau manfaat filsafat bagi manusia, demikian: "filsafat merupakan analogi dalam struktur pemikiran manusia, seperti semen yang menyatukan bangunan. Setumpuk batu bata bukanlah bangunan dan banyak fakta pengetahuan bukanlah pemahaman. Batu bata membutuhkan semen dan fakta memerlukan filsafat. ${ }^{27}$ Lebih lanjut dijelaskan bahwa filsafat adalah masalah hidup dan kebutuhan yang harus datang dari hati oleh pilihan pasti orang tersebut. Sebuah pilihan filosofis adalah pilihan beragama. Agama adalah satu-satunya titik tempat manusia dapat memperoleh gambaran tentang alam semesta. ${ }^{28}$

Secara umum, filsafat adalah upaya untuk berpikir dalam bentuk yang paling umum dan jelas sistematik dari segala sesuatu dalam alam semesta, tentang keseluruhan dari realitas. Dalam perspektif kristiani, kebutuhan akan filsafat pendidikan Kristen adalah upaya pada pencarian peran dan panggilan hidup manusia dalam Tuhan. Dalam pelayanan pendidikan, kebutuhan filsafat pendidikan berguna untuk membimbing pelayanan pendidikan agar keberadaannya sebagai sekolah Kristen sesuai Amanat Agung. ${ }^{29}$ Filsafat merupakan usaha manusia mencari dan memahami makna, panggilan dan arti dari kehidupan. Dalam Amsal 8:10-11 "terimalah didikanku, lebih dari perak, dan pengetahuan lebih dari pada emas pilihan. Karena hikmat lebih berharga daripada permata, apapun yang diinginkan orang, tidak dapat menyamainya." Bahkan filsafat mendorong seseorang untuk mencintai dan menghidupi hikmat. Pendidikan kristiani menegaskan bahwa Tuhanlah yang memberikan hikmat, bahkan dari mulut-Nya datang pengetahuan dan kepandaian (Ams. 2:6), dan bahkan filsafat kristiani mendorong orang Kristen untuk takut pada Tuhan sebagai permulaan untuk memperoleh hikmat dan pengetahuan (Ams. 1:7; 9:10). Dan bahkan klaim pendidikan Kristen bahwa dalam Kristus tersembunyi segala rahasia hikmat dan pengetahuan (Kol. 2:3).

Suatu tantangan bagi pendidik Kristen adalah mampukah dirinya berpikir dan bertindak secara kristiani dan secara benar dalam semua area kehidupan, termasuk area pendidikan secara selaras, harmonis seperti yang didengungkan Rasul Paulus "Jadi akhirnya saudara-saudara, semua yang benar, semua yang mulia, semua yang adil, semua yang suci, semua yang manis, semua yang sedap didengar, semua yang disebut kebajikan dan patut dipuji, pikirkanlah semuanya itu (Fil. 4:8).

\footnotetext{
${ }^{26}$ Robert W. Pazmino, Fondasi Pendidikan Kristen (Jakarta: BPK. Gunung Mulia, 2012), 323

${ }^{27}$ Paul A. Kienel, Gibbs Ollie E. Dan Berry Sharon E., editors, Philosophy of Chritian School Education (Colorado:ACSI Publisher, 1982), 91

${ }^{28}$ Paul A. Kienel, cs., Philosophy of Chritian School Education, 33

${ }^{29}$ Tung, Filsafat Pendidikan Kristen, 5.
} 
Para filsuf berusaha memecahkan masalah-masalah yang penting bagi manusia, baik langsung maupun tidak langsung, melalui pengujian yang kritis, filsuf mencoba mengevaluasi informasi-informasi dan kepercayaan-kepercayaan yang kita miliki tentang alam semesta serta kesibukan dunia manusia. Filsuf mencoba membuat generalisasi, sistematisasi, dan gambaran-gambaran yang konsisten tentang semua hal yang ia ketahui dan ia pikirkan. Secara umum misi filsafat terlihat dari tugas-tugas utamanya. Seperti yang dikatakan Titus (1959) yang mengemukakan bahwa terdapat tiga tugas utama filsafat, yaitu:

1. Mendapatkan pandangan yang menyeluruh

2. Menemukan makna dan nilai-nilai dari segala sesuatu

3. Menganalisis dan memadukan kritik terhadap konsep-konsep. ${ }^{30}$

Dari pemaparan di atas, kajian fondosi filosofis sangat bermanfaat bagi para pendidik untuk pengembangan kurikulum pendidikan Kristen.

\section{Memahami Pentingnya Filsafat bagi Pengembangan Kurikulum Pendidikan Kristen}

Sebagaimana diketahui bahwa filsafat adalah berpikir radikal, sistematis, dan universal terhadap segala sesuatu. Filsafat dipandang sebagai usaha mencari kebenaran, mencari sesuatu yang baik, berarti dan bernilai dari segala sesuatu yang mengelilingi manusia dalam alam semesta ini ${ }^{31}$. Maka para filsuf berusaha mencari dan mengembangkan misi filsafat bagi keutuhan dan kesejahteraan manusia. Selanjutnya dapat dipaparkan singkat betapa pentingnya filsafat bagi manusia termasuk dalam hal pendidikan dan pengembangan kurikulum.

\section{a. Memberikan jawaban alternatif bukan jawaban mutlak}

Filsafat tidak hanya sekedar ilmu pengetahuan atau fak-fak dalam mata kuliah. Filsafat adalah suatu tindakan, suatu aktivitas. Filsafat adalah aktivitas untuk berpikir secara mendalam tentang pertanyaan-pertanyaan besar dalam hidup manusia (apa tujuan hidup, apakah Tuhan ada, siapakah sesamaku manusia, siapakah jodohku, bagaimana menata suatu lembaga yang baik dan masyarakat yang majemuk, serta bagaimana hidup yang baik), dan mencoba menjawabnya secara rasional, kritis, dan sistematis. Filsafat tidak akan pernah bisa memberikan jawaban yang pasti dan mutlak, karena filsafat tidak memberikan jawaban mutlak, melainkan menawarkan alternatif cara berpikir.

b. Memampukan berpikir komprehensif namun logis, kritis dan sistematis

Dengan belajar filsafat, kita akan dilatih menjadi manusia yang berpikir utuh, yakni yang mampu berpikir mendalam, rasional, komunikatif. Kemampuankemampuan ini amat dibutuhkan. Di sisi lain, dengan belajar filsafat, kita juga akan memiliki pengetahuan yang luas tentang apapun termasuk terhadap sejarah manusia. Dengan belajar filsafat, kita akan mendapatkan beberapa keterampilan seperti memikirkan suatu masalah secara mendalam dan kritis, membentuk argumen dalam

\footnotetext{
${ }^{30}$ Sadulloh, Pengantar Filsafat Pendidikan, 25

${ }^{31}$ Uyoh Sadulloh, Pengantar Filsafat Pendidikan (Bandung: Alfa Beta, 2003), 27
} 
bentuk lisan maupun tulisan secara sistematis dan kritis, mengkomunikasikan ide secara efektif, dan mampu berpikir secara logis dalam menangani masalah-masalah kehidupan yang selalu tak terduga. Kemampuan berpikir logis dan abstrak, kemampuan untuk membentuk argumen secara rasional dan kritis, serta kemampuan untuk menyampaikan ide secara efektif, kritis, dan rasional, akan membuat kita mampu berkarya di berbagai bidang, mulai dari bidang informasi-komunikasi, jurnalistik, penerbitan, konsultan, pendidikan, rohaniawan, ataupun menjadi wirausaha.

Manfaat ilmu filsafat selanjutnya adalah berpikir kritis. Dengan berfikir kritis mengajarkan kita untuk mempelajari ha-hal yang tidak diketahui dan mencari tahu kenyataanya. Berfikir kritis merupakan aspek yang diperlukan karena tidak semua orang memiliki fikiran yang kritis. Berfikir kritis berarti berfikiran terbuka yang tidak hanya siap untuk dinasehati tetapi dikritisi dan dipermasalahkan namun kita tetap lapang hati dan berpikir luas. Ilmu filsafat adalah ilmu cerdas yang memberikan gambaran dalam berbagai cabang ilmu lainnya seperti pendidikan, ekonomi dan sosial. Sebagai ilmu yang cerdas ilmu filsafat ini lebih berkaitan dengan kehidupan sehari - hari dalam bersikap. Jadi penerapan ilmu filsafat sebagai ilmu cerdas sangatlah penting untuk dipelajari. Ilmu filsafat mengajarkan kecerdasan tidak hanya sebatas pada satu bidang saja melainkan juga secara keseluruhan. Manfaat ilmu filsafat ini penting diterapkan untuk anak-anak dimasa pertumbuhan mereka agar kemauan untuk belajar ilmu filsafaat sudah ada sejak dini.

Dengan belajar filsafat, kita akan mampu melihat masalah dari berbagai sisi, berpikir kreatif, kritis, dan independen, mampu mengatur waktu dan diri, serta mampu berpikir fleksibel di dalam menata hidup yang terus berubah. Filsafat mendorong kita untuk memahami dan mempertanyakan ide-ide tentang kehidupan, tentang nilai-nilai hidup, dan tentang pengalaman kita sebagai manusia. Berbagai konsep yang akrab dengan hidup kita, seperti tentang kebenaran, akal budi, dan keberadaan kita sebagai manusia, juga dibahas dengan kritis, rasional, serta mendalam. Filsafat itu bersifat terbuka. Sekali lagi, filsafat tidak memberikan jawaban mutlak yang berlaku sepanjang masa. Filsafat menggugat, mempertanyakan, dan mengubah dirinya sendiri. Ini semua sesuai dengan semangat pendidikan yang sejati. Filsafat mengajarkan kita untuk melakukan analisis, dan mengemukakan ide dengan jelas serta rasional. Filsafat mengajarkan kita untuk mengembangkan serta mempertahankan pendapat secara sehat, bukan dengan kekuatan otot, kekuatan massa, kekuasaan atau kekuatan otoritas politik semata.

Filsafat adalah komponen penting bagi pembentukan suatu kepemimpinan. Dengan belajar berpikir secara logis, seimbang, kritis, sistematis, dan komunikatif, kita akan menjadi seorang pemimpin ideal, yang amat dibutuhkan oleh berbagai bidang di Indonesia sekarang ini. ${ }^{32}$ Filsafat mencoba memadukan hasil-hasil dari berbagai sains yang berbeda ke dalam suatu pandangan dunia yang konsisten. Filosof cenderung untuk tidak menjadi spesialis, seperti ilmuwan. Ia menganalisis bendabenda atau masalah dengan suatu pandangan yang menyeluruh. Filsafat tertarik terahdap aspek-aspek kualitatif segala sesuatu, terutama berkaitan dengan makna dan nilai-nilainya. Filsafat menolak untuk mengabaikan setiap aspek yang otentik dari pengalaman manusia.

\footnotetext{
${ }^{32}$ Reza A.A Wattimena dalam https://rumahfilsafat.com/mengapa-kita-perlu-belajar-filsafat1/
} 
Kita sangat memerlukan suatu ilmu yang sifatnya memberikan pengarahan/ ilmu pengarahan. Dengan ilmu tersebut, manusia akan dibekali suatu kebijaksanaan yang di dalamnya memuat nilai-nilai kehidupan yang sangat diperlukan oleh umat manusia. Hanya ilmu filsafatlah yang dapat diharapkan mampu memberi manusia suatu integrasi dalam membantu mendekatkan manusia pada nilai-nilai kehidupan untuk mengenai mana yan gpantas kita tolak, man ayang pantas kita tujui, mana yang pantas kita ambil sehinga dapat memberikan makna kehidupan. Dengan belajar filsafat diharapkan kita akan dapat menambah ilmu pengetahuan, karena dengan bertambahnya ilmu akan bertambah pula cakrawala pemikiran dan pangangan yang semakin luas.

\section{c. Menjadi dasar semua tindakan.}

Sesungguhnya filsafat di dalamnya memuat ide-ide itulah yang akan membawa mansuia ke arah suatu kemampuan utnuk merentang kesadarannya dalam segala tindakannya sehingga manusia akan dapat lebih hidup, lebih tanggap terhadap diri dan lingkungan, lebih sadar terhadap diri dan lingkungan. Dengan adanya perkembangan ilmu pengethauan dan teknologi kita semakin ditentang dengan kemajuan teknologi beserta dampak negatifnya, perubahan demikian cepatnya, pergeseran tata nilai, dan akhirnya kita akan semakin jauh dari tata nilai dan moral. ${ }^{33}$ Maka sangat dibutuhkan pikiran jernih, sehat dan matang sehingga kita dimampukan mengambil keputusan dan tindakan yang tepat.

\section{d. Mengingatkan manusia untuk tidak menyombongkan diri}

Filsafat adalah ilmu kehidupan yang mempelajari berbagai kehidupan. Fenomena alam dan lain sebagainya. mempelajari alam sama dengan mempelajari hakekat kehidupan secara menyeluruh. Orang yang mengerti apa itu arti kehidupan menjadikannya lebih rendah hati dan tidak sombong karena itulah hakekat kehidupan. Hidup hanya sementara saja dan tidak akan selamanya. Semua yang kita miliki hanyalah titipan dari Tuhan dan hanya kita diijinkan memanfaatkan di dunia untuk kebaikan manusia dan kemuliaan bagi Tuhan.

\section{e. Mampu menyelesaikan masalah}

Manfaat selanjutnya dari ilmu filsafat selain mengajak untuk berfikir secara kritis juga bermanfaat untuk menyelesaikan masalah. Dalam kehidupan yang namanya masalah tentu akan selalu ada. Dan untuk menghadapi masalah memerlukan ketenengan lahir dan batin. Sehingga hasil yang didapat tidak disesali kemudian hari. Mampu menyelesaikan masalah secara baik membuktikan bahwa memiliki jiwa yang besar tidak semua orang punya. Hanya orang tertentu saja yang bisa melakukannya.

Jadi mempelajari ilmu filsafat dan memahami ilmu filsafat amat sangat penting untuk menentukan cara bersikap kita secara baik dalam menhadapi masalah dan menemukan solusi dari masalah tersebut. Menurut Harold H. Titus, filsafat adalah

${ }^{33}$ https://van88.wordpress.com/pengertian-subjek-objek-dan-pentingnya-filsafat/ 
suatu usaha memahami alam semesta, maknanya dan nilainya. Apabila tujuan ilmu adalah kontrol, dan tujuan seni adalah kreativitas, kesempurnaan, bentuk keindahan komunikasi dan ekspresi, maka tujuan filsafat adalah pengertian dan kebijaksanaan (understanding and wisdom). Sedangkan menurut Oemar A. Hoesin "Ilmu memberi kepada kita pengatahuan, dan filsafat memberikan hikmah. Filsafat memberikan kepuasan kepada keinginan manusia akan pengetahuan yang tersusun dengan tertib, akan kebenaran". S. Takdir Alisyahbana menuliskan "Filsafat itu dapat memberikan ketenangan pikiran dan kemantapan hati, sekalipun menghadapi maut. Dalam tujuannya yang tunggal (yaitu kebenaran) itulah letaknya kebesaran, kemuliaan, malahan kebangsawanan filsafat di antara kerja manusia yang lain. Kebenaran dalam arti yang sedalam-dalamnya dan seluas-luasnya baginya, itulah tujuan yang tertinggi dan satu-satunya."

Bagi manusia, berfilsafat itu berarti mengatur hidupnya seinsaf-insafnya, senetral-netralnya dengan perasaan tanggung jawab, yakni tanggung jawab terhadap dasar hidup yang sedalam-dalamnya, baik Tuhan, alam, atau pun kebenaran. Radhakrishnan dalam bukunya "History of Philosophy" menyebutkan: Tugas filsafat bukanlah sekadar mencerminkan semangat masa ketika kita hidup, melainkan membimbingnya maju. Fungsi filsafat adalah kreatif, menetapkan nilai, menetapkan tujuan, menentukan arah dan menuntun pada jalan baru. Filsafat hendaknya mengilhamkan keyakinan kepada kita untuk menompang dunia baru, mencetak manusia-manusia yang menjadikan penggolongan-penggolongan berdasarkan 'nation', ras, dan keyakinan keagamaan mengabdi kepada cita mulia kemanusiaan.

Filsafat tidak ada artinya sama sekali apabila tidak universal, baik dalam ruang lingkupnya maupun dalam semangatnya. Studi filsafat harus membantu orang-orang untuk membangun keyakinan keagamaan atas dasar yang matang secara intelektual. Filsafat dapat mendukung kepercayaan keagamaan seseorang, asal saja kepercayaan tersebut tidak bergantung pada konsepsi prailmiah yang usang, yang sempit dan yang dogmatis. Urusan (concerns) utama agama ialah harmoni, pengaturan, ikatan, pengabdian, perdamaian, kejujuran, pembebasan, dan Tuhan.

Berbeda dengan pendapat Soemadi Soerjabrata, yaitu mempelajari filsafat adalah untuk mempertajamkan pikiran, maka H. De Vos berpendapat bahwa filsafat tidak hanya cukup diketahui, tetapi harus dipraktekkan dalam hidup sehari-sehari. Orang mengharapkan bahwa filsafat akan memberikan kepadanya dasar-dasar pengetahuan, yang dibutuhkan untuk hidup secara baik. Filsafat harus mengajar manusia, bagaimana ia harus hidup secara baik. Filsafat harus mengajar manusia, bagaimana ia harus hidup agar dapat menjadi manusia yang baik dan bahagia. ${ }^{34}$ Dari kajian di atas tentunya fondosi filosofis sangat penting untuk pengembangan kurikulum pendidikan Kristen.

\section{HASIL}

\section{Tinjauan Filosofis Kedudukan Alkitab bagi Pengembangan Kurikulum Pendidikan Kristen}

\footnotetext{
${ }^{34}$ http://ratughina.blogspot.com/2016/12/pentingnya-filsafat-bagi-kehidupan.html
} 
Anggaran Dasar Persekutuan Antar Sekolah Teologia Injili Indonesia (PASTI) mengatakan:

"Kami percaya bahwa Alkitab adalah satu-satunya Firman yang diilhamkan Allah, yang ditulis oleh orang-orang yang dipilih Allah dibawah penguasaan dan pimpinan Roh Kudus tanpa salah dalam segala penyataan dan merupakan otoritas tertinggi dalam iman, tingkah laku dan sejarah." Dalam hal ini, kita mengetahui otoritas Alkitab dalam kehidupan orang percaya yaitu sebagai firman Allah yang diinspirasikan oleh Roh Kudus untuk menjadi pedoman kehidupan iman, karakter, pelayanan, dan pekerjaan. ${ }^{35}$

Homrighausen dan Enklaar mengatakan bahwa: Pertama, karena manusia percaya maka Alkitab menjadi mutlak. Kedua, Alkitab adalah kitab yang mutlak karena hanya kitab ini saja yanh menyampaikan Injil Tuhan Yesus Kristus, yaitu kabar baik tentang Juruselamat yang masuk ke dalam dunia untuk menebus segala dosa manusia. Ketiga, Alkitab menyatakan kepada manusia mengenai hubungan antara sesama manusia dengan Allah. ${ }^{36}$

Harry Piland menjelaskan "bahan-bahan kurikulum tidak pernah dapat dianggap sebagai pengganti untuk mempelajari Alkitab. Bahan-bahan pelajaran Alkitab disediakan untuk memberikan rencana pelajaran yang sistematis bagi setiap kelompok umur sebagai alat untuk belajar bagi para guru dan murid. Bahan-bahan tersebut dirancang untuk menolong orang-orang agar mengerti, menghargai, dan menerapkan Alkitab dalam kehidupan mereka sehari-hari". Kurikulum Pendidikan Kristen memandang Alkitab sebagai buku yang paling diperlukan sebagai pemberian ilahi. Seperti yang dikutip Colson Howard \& Rigdon Raymond dari Holmes Rolston dalam "the Bible in Christian Teaching" yang diterbitkan tahun 1962 bahwa "In Christian education we began with the Bible as the divine "given." It is the basis of all our curriculum. Without it there would be no Christian teaching. The Bible is the indispensable book." ${ }^{37}$ Apakah sifat dari Alkitab dalam kurikulum pendidikan Kristen?, Colson Howard \& Rigdon Raymond menyebutkan paling tidak ada tujuh sifat dasar Alkitab yang dapat disarikan bagi kurikulum pendidikan Kristen, yaitu: (1) The Bible is the record of God's self-revelation, (2) The Bible is the repository of God's redemptive message for the world, (3) The Bible is inspired by God (2 Tim.3:16, RSV; 2 Peter 1:21, RSV), (4) The Bible has been providentially preserved, (5) The Bible is God's gift to his church, (6) The Bible furnishes the only authoritative guidance for Christian life and work, (7) The Bible brings man to Christ. ${ }^{38}$ Terjemahan sederhana penulis tentang ketujuh hal tersebut: Alkitab adalah Wahyu khusus Allah, Alkitab adalah pesan penebusan Allah bagi dunia, Alkitab adalah diinspirasikan oleh Allah, Alkitab adalah pernyataan pemeliharaan Allah bagi dunia, Alkitab adalah pemberian Allah bagi gereja-Nya, Alkitab adalah satu-satunya penuntun berotoritas bagi kehidupan Kristen dan pekerjaan. Dan Alkitab membawa manusia kepada Kristus.

Oleh karena itu Alkitab memiliki tempat atau kedudukan istimewa dalam Kurikulum Pendidikan Kristen sebagaimana dituliskan Howard \& Raymond yaitu: (1) The Bible is the source of Christian teaching, (2) The Bible is the norm for Christian

\footnotetext{
${ }^{35}$ Dyulius Thomas Bilo, "Fondasi Alkitabiah Dalam Pengembangan Kurikulu, Pendidikan Kristen" dalam Melayani Dengan SETIA: Misi GKSI Dalam Tangan Tuhan, 138

${ }^{36}$ E.G. Homrighausen \& Enklaar, Pendidikan Agama Kristen (Jakarta: BPK. Gunung Mulia, 1997), 63

${ }^{37}$ Colson Howard \& Rigdon Raymond, Understanding Your Church's Curriculum (Nashville: Broadman Press, 1981), 104.

${ }^{38}$ Howard\&Raymond, Understanding Your Church's Curriculum, 104-105
} 
teaching, (3) The Bible is the instrument for Christian teaching. ${ }^{39}$ Secara sederhana dapat diterjemahkan: Alkitab adalah sumber utama pengajaran Kristen, Alkitab adalah norma atau standar pengajaran Kristen, dan Alkitab adalah alat-alat pengajaran Kristen.

\section{Tinjauan Filosofis terhadap Alkitab Penentu Isi Pengembangan Kurikulum Pendidikan Kristen}

Richard J. Edlin mengintisarikan pemahamnya tentang Alkitab penentu isi kurikulum sekolah Kristen bahwa kekristenan diawali dengan sebuah keyakinan kepada Pencipta yang pribadi yang menyatakan Diri-Nya melalui firman-Nya-firmanNya dalam ciptaan, firman-Nya yang hidup dalam Yesus Kristus, dan firman-Nya yang tertulis dalam Kitab Suci baik Perjanjian Lama maupun Perjanjian Baru. Jauh melebihi semua analisis, penyelidikan intelektual, atau aktivitas manusia, dengan penuh kesadaran kita tunduk pada otoritas Alkitab sebagai firman Allah tertulis dan sempurna yang jelas terbukti, bersifat nubuat, dan benar. Dengan demikian, orang Kristen diawali dengan keyakinan bahwa Alkitab adalah buku paling penting di dunia-terkemuka, tertinggi, dan sangat unik dalam otoritasnya, tujuan, dan dampaknya. Posisi lain apa pun mungkin akan menempatkan mekanisme sahih di atas Alkitab dan mekanisme sahih itu pun akan menjadi otoritas tertinggi. ${ }^{40}$

\section{Tinjauan Filosofis Alkitab Penentu Arah dan Tujuan Pengembangan Kurikulum Pendidikan Kristen}

Tidak hanya sekedar tujuan (purpose) tetapi lebih pada tujuan dalam arti telos, yaitu tujuan ke arah mana kita melakukan pendidikan Kristen. Arah ini akan menjadi tujuan utama (ultimate purpose) kita mengembangkan kurikulum pendidikan Kristen. Thomas Grome mengusulkan hendaknya menjadi tujuan utama kita menjalankan pendidikan Kristen adalah untuk menuntun orang-orang ke luar menuju kerajaan Allah di dalam Yesus Kristus. Dengan menunjukkan tiga alasan. ${ }^{41}$ Pertama, dalam kitab suci orang Yahudi visi kerajaan Allah ditempatkan sebagai visi dan rencana Allah sendiri bagi seluruh manusia dan ciptaan.

Kedua, dalam kesinambungan dengan dan dalam tradisi orang Yahudi itu, Yesus memberitakan Kabar Baik-Nya. Yesus, yang orang-orang Kristen kenal sebagai Kristus, menjalani kehidupan-Nya dan memberitakan Injil-Nya bagi Kerajaan Allah. Demikianlah tujuan-Nya. Tujuan-Nya seharusnya juga menjadi tujuan orang-orang yang akan mendidik dalam nama-Nya. Ketiga, meskipun Kerajaan Allah sebagai tema utama pemberitaan Kristen mengalami stagnasi di Gereja mula-mula, Kerajaan Allah telah menjadi yang utama kembali dalam teologi kontemporer. Meskipun ada banyak perbedaan pendapat di diantara para teolog dan para pakar kitab suci dewasa ini mengenai makna kerajaan Allah, ada juga kesepakatan utama bahwa Kerajaan Allah adalah tema utama dari kitab-kitab Injil dan orang-orang Kristen yang hidup harus

\footnotetext{
${ }^{39}$ Howard\&Raymond, Understanding Your Church's Curriculum, 105-106

${ }^{40}$ Richar J. Edlin, Hakikat Pendidikan Kristen (Jakarta: BPK. Gunung Mulia, 2015), 111

${ }^{41}$ Dyulius Thomas Bilo, "Fondasi Alkitabiah Dalam Pengembangan Kurikulu, Pendidikan Kristen" dalam Melayani Dengan SETIA: Misi GKSI Dalam Tangan Tuhan, 155
} 
merespons kerajaan itu. Pendidikan Agama Kristen memiliki tujuan mempromosikan respons yang demikian. ${ }^{42}$

Nicholas P. Wolterstorff mengatakan bahwa kurikulum sekolah adalah hasil dari keputusan-keputusan seputar apa yang akan diajarkan kepada sesama kita dan yang tidak akan diajarkan kepada mereka, apa yang akan ditekankan dan apa yang tidak akan ditekankan. Yang perlu sekali disini adalah bagaimana mengambil keputusankeputusan yang menghasilkan kurikulum sekolah. Harapan dari pada kurikulum sekolah hendaknya memberikan hasil dan persepsi yang jelas tentang ciri-ciri kehidupan Kristen yang kreatif, dinamis, berani dan terutama mencapai tujuan kurikulum pendidikan Kristen itu sendiri yaitu memperlengkapi para murid untuk mengarungi kehidupan Kristen. Ciri-ciri utama dari kehidupan Kristen yang hendaknya berimplikasi pada penyusunan dan pengembangan kurikulum pendidikan Kristen, sebagai berikut: Pertama, kehidupan Kristen adalah kehidupan seorang pribadi, seorang manusia. Kedua, kehidupan Kristen adalah kehidupan iman; yaitu bukan yang mencakup iman, melainkan kehidupan yang sebagai satu keutuhan adalah kehidupan iman. Ketiga, kehidupan Kristen adalah kehidupan seseorang yang merupakan anggota komunitas Kristen. Keempat, kehidupan Kristen adalah kehidupan yang harus dijalani di tengah masyarakat umum. Kelima, kehidupan Kristen adalah kehidupan yang menolong pelaksanaan tugas penaklukkan budaya. Beranjak dari kelima poin ini, Nicholas P. Wolterstorff menekankan hanya satu poin utama, yakni: Pendidikan dan kurikulum pendidikan Kristen adalah untuk kehidupan Kristen. 43

\section{Kesimpulan}

Dari penjelasan di atas, menyadarkan para pelaku pendidikan Kristen bahwa penyusunan dan pengembangan kurikulum pendidikan Kristen tidak dapat dipisahkan dari fondasi filosofisnya. Kurikulum pendidikan Kristen adalah untuk pembentukan kehidupan spritualis seperti Yesus. Sangat diperlukan pemikiran dan praktik pendidikan yang mendasarkan prinsip-prinsip filosofisnya pada Alkitab. Hal ini bagi para pendidik Kristen akan memberikan dasar-dasar universal yang bersifat kultural dan transkultural dalam rangka memandu pola pikir dan praktik pengembangan kurikulum pendidikan Kristen. Dengan demikian tantangan bagi pendidik Kristen untuk mengartikulasikan sebuah skema pemikiran yang sistematis dan memberikan kehidupan yang berfungsi untuk meletakkan dan memandu prinsip dan praktik pengembangan kurikulum pendidikan Kristen.

\footnotetext{
${ }^{42}$ Thomas H. Grome, Christian Religius Education (Jakarta: BPK. Gunung Mulia, 2010), 49-51

${ }^{43}$ Nicholas P. Wolterstorff, Mendidik untuk Kehidupan (Surabaya: Momentum, 2007), 11-23
} 


\section{DAFTAR PUSTAKA}

Edlin Richar J., Hakikat Pendidikan Kristen.Jakarta: BPK. Gunung Mulia, 2015.

Grome Thomas H., Christian Religius Education. Jakarta: BPK. Gunung Mulia, 2010.

Hamalik Oemar, Kurikulum dan Pembelajaran. Jakarta: Bumi Aksara, 2011.

Holmes Arthur F. ed., The Making of a Chritian Mind; A Christian Worldview and the Academic Enterprise. Downers Grove, IL:InterVarsity, 1985.

Homrighausen E.G. \& Enklaar, Pendidikan Agama Kristen. Jakarta: BPK. Gunung Mulia, 1997.

Howard Colson \& Rigdon Raymond, Understanding Your Church's Curriculum. Nashville: Broadman Press, 1981.

Jalaluddin H. dan Abullah Idi, Filsafat Pendidikan: Manusia, Filsafat dan Pendidikan, 12.

Kienel Paul A., Gibbs Ollie E. Dan Berry Sharon E., editors, Philosophy of Chritian School Education. Colorado:ACSI Publisher, 1982.

Latif Muktar, Orientasi ke Arah Pemahaman Filsafat Ilmu. Jakarta: Prenadamedia Group, 2014.

LeBar Lois E., "Curriculum," dalam An Introduction to Evangelical Christian Education, ed. J. Eward Hakes. Chicago:Mody, 1964.

Mason Charlotte, Home School Education, Home Education Series vol. 8, edisi ke-6. Oxford Scrivener, 1953.

Nasution S., Asas-asas Kurikulum. Jakarta: Bumi Aksara, 2008.

Pazmino Robert W., Fondasi Pendidikan Kristen. Jakarta: BPK. Gunung Mulia, 2012.

Tim Pengembang MKDP Kurikulum dan Pembelajaran, Kurikulum dan Pembelajaran. Jakarta: Rajawali Pers, 2011.

Sadulloh Uyoh, Pengantar Filsafat Pendidikan. Bandung: Alfa Beta, 2003.

Sanjaya Wina, Kurikulum dan Pembelajaran. Jakarta: Kencana Prenada Media Group, 2009.

Tanya Eli, Gereja dan Pendidikan Agama Kristen. Cipanas: STTC, 2006.

Tim BPS GKSI, Melayani Dengan SETIA: Misi GKSI Dalam Tangan Tuhan. Jakarta: Delima-BPS GKSI, 2018

Tung Khoe Yao, Filsafat Pendidikan Kristen. Yogyakarta: Andi, 2013.

Wolterstorff Nicholas P., Mendidik untuk Kehidupan. Surabaya: Momentum, 2007. 